\title{
Can States Impose Registration Requirements on Online Charitable Solicitors?
}

\author{
Melissa G. Liazos $\dagger$
}

States have regulated charities for at least the past four hundred years.' Such regulations protect charitable institutions by ensuring that only legitimate charitable organizations receive the tax and other benefits accorded to nonprofits with a public purpose. They also protect consumers from fraud and abuse. ${ }^{3}$ State regulations seek to prevent the "fraud and unethical behavior [that is commonly reported] in [the] daily newspapers." Solicitation laws further aim to protect the public interest and provide a source of information on charities. Thirty-eight states and the District of Columbia require charities to register in-state and file financial and other information prior to soliciting in those states.

Charities have expanded their traditional fundraising methods and are increasingly raising significant amounts of money through the Internet. In one month in 1999, the Red Cross raised over $\$ 1$ million online to aid Kosovo refugees. ${ }^{7}$ World Vision, a Christian humanitarian group that sends relief workers throughout the world and spon-

$\dagger$ B.A. 1996, Harvard College; J.D. Candidate 2001, The University of Chicago.

1 See Acte to redresse the Misemployment of Landes Goodes and Stockes of Money heretofore given to Charitable Uses ("Statute of Charitable Uses"), 43 Eliz ch 4 (1601) (permitting bishops and commissioners to inquire into the uses of charitable funds).

2 See Internal Revenue Code ("IRC") § 501(c)(3), codified at 26 USC § 501(c)(3) (1994) (describing various allowable public purposes for nonprofit corporations and the requirements they must meet to qualify for tax exemption).

3 See Village of Schaumburg v Citizens for a Better Government, 444 US 620, 636-38 (1980) (stating that government entities may enforce their substantial interests in protecting the public from fraudulent, criminal, and annoying charitable solicitations through regulating solicitations, as long as government regulation does not merely peripherally promote these interests and does not "unnecessarily interfer[e] with First Amendment freedoms").

4 Avner Ben-Ner and Theresa Van Hoomissen, The Governance of Nonprofit Organizations: Law and Public Policy, 4 Nonprofit Management \& Leadership 393, 393 (1994) (citing nonprofit fraud cases of "Jim and Tammy Bakker at PTL (Praise The Lord), William Aramony of the United Way, and New York State Blue Cross and Blue Shield").

5 See David E. Ormstedt, State Authority to Regulate Charitable Solicitation, 287 PLI/Tax 67,69 (1989).

6 See <http://www.nonprofits.org/library/gov/urs> (visited Mar 4,2000) (including a list of states that require charitable solicitors to register, and a list of states that use the Uniform Registration Statement).

7 See Leslie Miller, Charity Begins on Line: Nonprofit Groups Raise Millions Without Phone Calls or Junk Mail, USA Today 6D (May 5, 1999). 
sors children, raises over $\$ 183,000$ per month on the web. ${ }^{8}$ Fundraising online is not limited to efforts by charities themselves. Internet auction sites have organized fundraisers for charities, and other web sites donate a percentage of their sales to charity. Estimates suggest that three and a half million people have already used the Internet to make a charitable contribution. ${ }^{10}$ It is also possible to donate to a charity through an umbrella web site such as www.guidestar.org or www.helping.org, even though the recipient charity may not solicit on the web or even maintain a web page. ${ }^{11}$ The expansion of online solicitation has also greatly increased possibilities for consumer fraud. ${ }^{12}$

The increased use of the Internet for fundraising presents the issue of whether a charity that raises money via a web site will be required to register in every jurisdiction where its web site is accessible. Some states have indicated that they believe charities that solicit online must register in their states. As early as 1995, state officials in Massachusetts, Connecticut, New York, and Pennsylvania took the position that online fundraising was covered by their respective statutory definitions of solicitation, thus potentially requiring registration. ${ }^{13}$ The Illinois and Minnesota Attorneys General's offices have actively pursued online violators of their respective state laws. ${ }^{14}$ States currently pursuing and fining unregistered nonprofits that solicit online include South Carolina, Florida, and Pennsylvania. ${ }^{15}$ While no state regulators have yet demanded that charities soliciting in their state solely via a web site register, this is mainly because Internet solicitation remains

8 See id.

9 See id.

10 See Joellen Perry, Charities Solicit Online With Pitches and Fruitcakes, US News \& World Rep 78 (Nov 29, 1999).

11 See <http://www.guidestar.org/give/index.html> (visited Feb 10, 2000) and <http://www.helping.org> (visited Feb 10, 2000). These sites enable their visitors to search a database of charities and to chose an organization to which to donate. With Guidestar, for example, the entire value of a donation, less a processing fee of not more than 2 percent, is transferred to the charity. The costs of the Guidestar web site are borne by the AOL Foundation. A search of these sites revealed that it is possible to make an online donation to a charity, for example Operation Aware of Tulsa, Oklahoma, that does not maintain its own web page and therefore cannot solicit on its own via the Internet.

12 Charles A. Jaffe, Check Their Line: Resist the Lure of Charities Until You Have a Chance to Investigate, Chi Trib 1 (Dec 22, 1999) (noting that while the Internet has given consumers more options for charitable donations, it has also "made it equally easy for scam artists to hit on consumers").

13 See Betsy Hill Bush, Internet Solicitation: Registration Required, The Nonprofit Times 26 (July 1995).

14 See Dan L. Burk, Federalism in Cyberspace, 28 Conn L Rev 1095, 1096 (1996).

15 See Ali Woolwich, Review of an Internet Fundraising Seminar, Nonprofit Online News, available online at <http://www.gilbert.org/news/features/feature0021.html> (visited Feb 10, 2000) (including a review of seminar for nonprofits on strategies for raising money online, and noting that South Carolina, Florida, and Pennsylvania are currently pursuing and fining nonregistered online solicitors). 
so new - not because regulators believe that registration requirements do not apply. ${ }^{16}$ Many regulators have indicated that they will interpret current state registration laws to apply to online solicitors."

While states routinely impose their registration requirements on out-of-state charities that solicit in-state in "real space," the Internet poses new challenges for states and charities in this arena. ${ }^{19}$ Charities that solicit contributions via a web site face the possibility of having to register in every jurisdiction in the United States that so requires, which would pose a significant burden on their ability to operate, especially for smaller charities with limited resources. Furthermore, state attempts to regulate out-of-state charities that solicit via the Internet may raise federal-state dormant Commerce Clause concerns, as well as state-to-state Commerce Clause concerns relating to states regulating commerce outside of their borders and leading to conflicting state regimes. Faced with the new medium of the Internet, commentators have argued that states both $\operatorname{can}^{20}$ and cannot ${ }^{21}$ regulate the

16 See <http:/www.muridae.com/nporegulation/foreign_solicitation.html> (visited March 4,2000 ).

17 See id.

18 See, for example, the Minnesota Attomey General's home page, which includes a database of charities registered to solicit in-state and enables one to search the database by state. <http://www.ag.state.mn.us/cgi-bin/charitysearch.taf> (visited March 4, 2000). A search under "CA" revealed that there are 121 California charities registered in Minnesota; a search under "NY" revealed 151 charities from New York registered in Minnesota. The database indicates that charities from forty states and the District of Columbia are registered in Minnesota.

19 States traditionally have been the locus of charitable regulation, although the federal government has played a role as well. See, for example, IRC $\$ 501$ (c)(3) (providing tax exemption for qualifying charitable organizations). There have been past proposals for the federal government to play an even larger role in this area. The Filer Commission, under the rubric of the United States Treasury, proposed establishing a national supervisory agency to oversee nonprofits in 1977. See Commission on Private Philanthropy and Public Needs, Commentary on Commission Recommendations, in 1 Filer Commission Research Papers 3, 38 (Treasury Dept 1977). These have included proposals to regulate aspects of solicitation, including proposals to require exempt organizations to disclose the percentage of funds raised that are spent on exempt purposes and to require professional fundraisers to reveal the percent of the money they collected that went to costs. See Leslie G. Espinoza, Straining the Quality of Mercy:Abandoning the Quest for Informed Charitable Giving, 64 S Cal L Rev 605, 672 (1991).

20 Consider Lawrence Lessig, The Law of the Horse: What Cyberlaw Might Teach, 113 Harv L Rev 501, 506 (1999) ("[W]hile particular versions of cyberspace do resist effective regulation, it does not follow that every version of cyberspace does so as well.... [T] here are versions of cyberspace where behavior can be regulated, and the government can take steps to increase this regulability."); Jack L. Goldsmith, Against Cyberanarchy, 65 U Chi L Rev 1199, 1200-01 (1998) (arguing that regulation of cyberspace is feasible; states have adapted their regulatory regimes to technological innovations in the past and can do so in the context of the Internet); James Boyle, Foucault in Cyberspace: Surveillance, Sovereignty, and Hardwired Censors, 66 U Cin L Rev 177, 178 (1997) ("[T] evade some of the supposed practical (and constitutional) restraints on the exercise of legal power over the Internet.").

21 Consider John T. Delacourt, The International Impact of Internet Regulation, 38 Harv Intl L J 207, 208 (1997) (contending that Internet regulations imposed by the United States and other countries will be ineffective); Burk, 28 Conn $L$ Rev at 1096-97 (cited in note 14) (arguing 
Internet, although they have not necessarily made normative claims about whether states should do so.

Despite potential concerns regarding jurisdiction, the dormant Commerce Clause, and inconsistent regulation, charities, like other organizations that conduct transactions online, should not be able to escape regulation and consumer protection statutes simply by virtue of the fact that they operate on the web. This Comment argues that it is feasible and desirable for states to regulate online solicitors in their jurisdictions in order to continue to police consumer fraud, that charities that obtain the benefits of solicitation should bear the burdens associated with such activity, and that such regulation would not violate the affirmative or the dormant Commerce Clause.

Part I provides an overview of the development of state and federal supervision of charities, with a particular focus on solicitation laws. This Part demonstrates that although the federal government does regulate charities in some respects, states serve as the primary regulators of charities' solicitation efforts. Part II examines questions of personal jurisdiction, Commerce Clause concerns, and federal policy in the context of the Internet. It demonstrates that states should be able to obtain jurisdiction over a nonprofit organization whose only connection to the forum state is an online solicitation; and in addition, because there is no discrimination in such regulation, it asserts that many traditional Commerce Clause concerns are alleviated. Part III argues that there should be regulation of online solicitations and that this is best done by states, since they have the strongest interest in protecting their citizens from fraud. Part IV proposes how to facilitate this regulation.

\section{History OF THE REGULATION OF CHARITIES AND SOLICITATION}

States are almost exclusively responsible for overseeing charities, with the goal of "minimiz[ing] opportunities for deceptive fundraising." The federal government's role is generally limited to establishing contribution incentives ${ }^{23}$ and requiring the disclosure of informa-

that Due Process Clause of the Fourteenth Amendment and the dormant Commerce Clause significantly limit states' abilities to regulate online activities); David R. Johnson and David Post, Law and Borders-The Rise of Law in Cyberspace, 48 Stan L Rev 1367, 1367 (1996) (arguing that the Internet defies territorial regulation and that authorities should therefore defer to selfregulation in cyberspace); Joel R. Reidenberg, Governing Networks and Rule-making in Cyberspace, 45 Emory L J 911,921-23 (1996) (stating that current American regulatory paradigms are too narrowly targeted to regulate effectively the Internet).

22 Developments in the Law: Nonprofit Corporations, 105 Harv L Rev 1578, 1636 (1992).

23 Id. State governments provide contribution incentives as well. 
tion that ensures that only truly charitable organizations receive the benefits of tax exemption. ${ }^{24}$

Significantly, state law has evolved to require all charities that solicit in the state to register there. These statutes are aimed at protecting the public from fraud and abuse. Various portions of solicitation statutes have been struck down over the years, limiting states' ability to police fraud. However, this policing remains an essential goal of state regulation. The federal government is only involved in charitable supervision through the Internal Revenue Service, although there have been (unsuccessful) proposals in the past to expand the federal government's role in this area.

\section{A. State Regulation}

Governments have regulated charitable organizations for almost four hundred years, beginning with the Statute of Charitable Uses in England in $1601{ }^{25}$ In the early United States-in fact, up until the 1900 s - charities existed mainly in trust form and were supervised at the local level. ${ }^{26}$ Early on, the Supreme Court held that charitable corporations were to be treated the same as private corporations, which protected charitable corporations from state interference with their charters. ${ }^{27}$ Otherwise, the state could have altered a charity's charter as it desired, potentially discouraging donors. ${ }^{23}$ While many charities existed as trusts, incorporation became an increasingly popular form of charitable organization in the early $1900 \mathrm{~s}^{29}$ Trusts are limited by the Rule Against Perpetuities, and thus in the income they can accumulate, while charitable corporations are not; further, founders and directors of charitable corporations tend to have far more autonomy than do trustees. ${ }^{30}$ A state's cy pres powers also do not reach charitable corporations. Thus, with the rise of incorporation as a form of charitable organization, states lost some of the tools they had used to police

24 See IRC $\$ 501$.

2543 Eliz ch 4 (1601).

26 See Espinoza, 64 S Cal L Rev at 636-38 (cited in note 19) (noting barriers to regulation of trusts by state attorneys general); James J. Fishman, The Development of Nonprofit Corporation Law and an Agenda for Reform, 34 Emory L J 617, 619 (1985). Although charitable trusts are still the predominant form of charitable organization in England, charitable trusts and corporations are treated very similarly there, leading in essence to a uniform law. See Fishman, 34 Emory L J at 619-21.

27 See Fishman, 34 Emory L J at 642 (cited in note 26).

28 Id.

29 See Evelyn Brody, Institutional Dissonance in the Nonprofit Sector, 41 Vill L Rev 433, 475 (1996) (noting the divergence in American and English charities laws as American charities increasingly took corporate form).

30 Id.

31 Id. 
charities and potential fraud. By the 1950s, three-fourths of all foundations were incorporated. ${ }^{32}$

In 1943, New Hampshire passed the first statute requiring charities to report to the state Attorney General. ${ }^{33}$ By 1959, twenty-one states had statutes that regulated charities in a similar manner. ${ }^{34}$ Such statutes gained widespread support, for they ensured that only legitimate charitable organizations received the benefits granted to nonprofit organizations with a public purpose. In the early 1960s, the Hamlin Committee, formed by the Rockefeller Foundation and private citizens, issued a report supporting state regulations that required financial reporting by charitable organizations to a central state agency.

Prior to 1980 , most state charitable solicitation statutes contained three elements: "(1) registration and reporting requirements for soliciting charities and fundraising professionals; (2) prohibitions against fraud and misrepresentation, including required disclosures; and (3) stringent limitations on fundraising costs." ${ }^{36}$ Limits on fundraising costs were enacted in response to an exponential growth in solicitation after World War II that was made possible by advances in communication and technology. Such advances, however, also increased the possibilities for fraud and inefficiency, ${ }^{37}$ in a process somewhat analogous to the growth of the Internet today.

However, states encountered difficulties in drafting charitable solicitation statutes that could withstand constitutional challenge. In Village of Schaumburg $v$ Citizens for a Better Government, ${ }^{38}$ the Supreme Court struck down as invalid under the First and Fourteenth Amendments an ordinance that prohibited door-to-door canvassing unless at

32 See Espinoza, 64 S Cal L Rev at 642 (cited in note 19). For a model of nonprofit incorporation laws, see the Revised Model Nonprofit Corporation Act (ABA 1987). "The original Model Non-profit Corporation Act was approved by the Committee on Corporate Laws of the Section of Corporation, Banking, and Business Law of the American Bar Association in 1952." Lizabeth A. Moody, The Who, What, and How of the Revised Model Nonprofit Corporation Act, $16 \mathrm{~N}$ Ky L Rev 251, 251 (1989). State attorneys general have authority over nonprofit corporations through the not-for-profit corporation laws and over charitable trusts through laws relating to charitable trusts. They have general authority over charities through the registration and reporting laws, as well as laws that give the attorney general authority over specified events in the life cycle of the nonprofit. Harriet Bograd, The Role of State Attorneys General in Relation to Troubled Nonprofits 22 (Yale Inst for Soc \& Pol Stud 1994).

33 See An Act Establishing A Register of Public Trusts, 1943 NH Laws 181 (authorizing the Attorney General to establish and maintain a registry of public trusts).

34 Espinoza, 64 S Cal L Rev at 648 \& n 204 (cited in note 19).

35 See id at 649-51, citing Robert $\mathrm{H}$. Hamlin, ed, Voluntary Health and Welfare Agencies in the United States: An Exploratory Study by an Ad Hoc Citizens Committee i-ii, 2-37 (1961).

36 Elaine Waterhouse Wilson, State Regulation of Charitable Solicitation, 12 Prob \& Prop 48, 48 (July-Aug 1998).

37 See Espinoza, 64 S Cal L Rev at 635 (cited in note 19).

38444 US 620 (1980). 
least 75 percent of the money raised went directly to charitable activities. $^{39}$ The Court found that the 75 percent requirement did not serve any legitimate government interest, such as protecting public safety or preventing fraud. ${ }^{41}$ While states can regulate charities to protect these interests, the Court reiterated that charitable solicitation is protected First Amendment speech."

After Citizens for a Better Government, a number of states kept their percentage limits on administrative costs, but amended their statutes to allow a charity to demonstrate that administrative costs in excess of the statutory limits were reasonable. ${ }^{42}$ However, in Secretary of State of Maryland v Joseph $H$. Munson $\mathrm{Co}$, Inc ${ }^{43}$ the Supreme Court struck down a solicitation statute with just such a waiver provision." Due to the Court's rulings in Citizens for a Better Government and Munson, states lost the ability to use percentage limits to protect donors and to maximize the productivity of the charitable sector.

Following Munson, the National Association of Attorneys General ("NAAG") and the National Association of State Charity Officials ("NASCO") formulated A Model Act Concerning the Solicitation of Funds For Charitable Purposes." The Model Act aimed to encourage "uniform, fair, and effective legislation regarding charitable solicitations." The Act was also drafted in part "to address the Supreme Court's first amendment concerns elaborated in Citizens for a Better Government and Munson." The Model Act requires all charitable organizations that are not exempt to register in a state prior to soliciting there. The Act places greater registration and reporting requirements on professional fundraisers than on nonprofessional fundraisers. ${ }^{50}$ The

39 Id at 622.

40 Id at 636-38.

41 Id at 632.

42 See Wilson, 12 Prob \& Prop at 49 (cited in note 36 ).

43467 US 947 (1984).

44 Id at $949-50$.

45 See Espinoza, 64 S Cal L Rev at 607-08 (cited in note 19) (describing goals of statutes limiting fundraising costs).

46 National Association of Attorneys General Committee on Trusts and Solicitations, $A$ Model Act Concerning the Solicitation of Funds for Charitable Purposes ("Model Act") (National Association of Attorneys General 1986), available online at <http://www.muridae.com/ nporegulation/documents/model_solicitations_act.html> (visited Feb 11,2000).

47 Private Sector Advisory Group to the NAAG/NASCO Model Solicitations Law Project, Resolution, passed Oct 7, 1986, available online at <http://www.muridae.com/nporegulation/ documents/model_solicitations_act.html > (visited March 4,2000).

48 Wilson, 12 Prob \& Prop at 50 (cited in note 36).

49 Model Act $\$ 2$ (a) (cited in note 46). Exempt groups include political parties, political action committees, political candidates, persons exempt from filing annual federal information returns under the Internal Revenue Code, groups that raise less than a set amount of money, and groups that have less than ten donors, no employees, and do not pay for fundraising assistance. Id at $\$ 4(\mathrm{a})-(\mathrm{c})$.

50 Id at $\$ 6$. Even at the time of the approval of the Model Act by NAAG, an advisory 
Act also defines solicitation broadly, ${ }^{\text {st }}$ although it does not mention the Internet, as the Model Act was written prior to the Internet's widespread use. The Act does not define where a solicitation occurs, though states may find that a solicitation occurs where the consumer receives it. ${ }^{52}$ The Model Act is the basis for most state charitable solicitation law. ${ }^{53}$

In 1988, in Riley v National Federation of the Blind of North Carolina, Inc, ${ }^{\text {st }}$ the Supreme Court struck down a portion of North Carolina's charitable registration statute, which, though passed prior to the Model Act, was similar to Section 6 of the Act. ${ }^{\text {ss }}$ Specifically, the Court invalidated three provisions under the First Amendment: (1) a prior registration requirement imposed on professional solicitors that did not apply to nonprofessional solicitors, (2) a requirement that professional fundraisers disclose their percentage of compensation from previous campaigns, and (3) a percentage requirement, with a waiver provision, on how much money raised must go directly to charity. Once again, the Court expressly held that charitable solicitation is protected as First Amendment speech. ${ }^{57}$ However, the Court failed to distinguish between charitable programming (the day-to-day services that the charity provides) and requests for money. ${ }^{\text {ss }}$ The two do not necessarily deserve the same level of deference nor do they merit the same regulatory treatment.

Despite Riley, other parts of the Model Act that are not related to the invalidated North Carolina statute remain viable and several

group expressed strong concern over Section 6(e)(1)(B), which required paid solicitors to disclose, when requesting a contribution, that only a fixed percentage of the revenues raised would go to charity. Private Sector Advisory Group, Resolution (cited in note 47). The Supreme Court later invalidated a North Carolina statute that contained provisions similar to this and other provisions of Section 6 in Riley $v$ National Federation of the Blind of North Carolina, 487 US 781 (1988). See text accompanying notes 54-56.

51 Model Act $\$ 1$ (c) (cited in note 46). Specifically, the Act defines solicit or solicitation to mean "the request directly or indirectly for money, credit, property, financial assistance, or other thing of any kind or value on the plea or representation that such money, credit, property, financial assistance, or other thing of any kind or value, or any portion thereof, will be used for a charitable purpose or benefit a charitable organization." Id.

52 For example, Arkansas law states that a "[s]olicitation' shall be deemed to occur when the request is made, at the place the request is received, whether or not the person making the same actually receives any contribution." Act to Regulate the Solicitation of Charitable Funds in Arkansas, Ark Code Ann Act 1198 \& 1(13) (Lexis Advance Legislative Service 1999). See also Wilson, 12 Prob \& Prop at 51 (cited in note 36) (justifying this approach as the best method of protecting consumers).

53 Wilson, 12 Prob \& Prop at 52 (cited in note 36) ("[M]ost charitable solicitation statutes have the common heritage of the Model Act.").

54487 US 781 (1988).

55 See id at 784.

56 See id at $785-87$.

57 See id at 787-88.

58 See Espinoza, 64 S Cal L Rev at 625 (cited in note 19). 
states have adopted them. Significantly, the Model Act contains a reciprocity provision that enables officials in one state to accept information filed by a charity in another state in lieu of a separate filing. ${ }^{59}$ A number of states have adopted this provision, ${ }^{6}$ and NAAG and NASCO have developed a uniform registration form that most states currently use, ${ }^{61}$ enabling charities to avoid duplicate filings.

Currently, thirty-eight states and the District of Columbia require charitable organizations that intend to solicit contributions in-state to register with state officials and to report specified information prior to

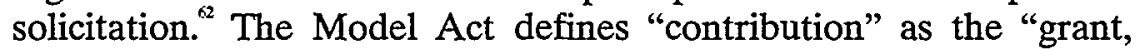
promise or pledge of money, credit, property, financial assistance or other thing of any kind or value in response to a solicitation." ${ }^{63}$ Most states follow this definition or have a more narrow one. ${ }^{64}$ Some states require registration and reporting by all charities, while some require it only of those that solicit funds. ${ }^{65}$ Some states define charitable organizations to include only those that do business or hold property in the state, ${ }^{6}$ although at what point solicitation constitutes "doing business" is unclear.

Further, while the Model Act defines charitable organizations to include tax-exempt organizations as well as self-described charitable groups, ${ }^{67}$ some states have eliminated this latter portion from their definition of charitable organizations, requiring only groups that are in fact charitable to register. ${ }^{68}$ These states typically require charities to register with a designated state official, pay a filing fee, and disclose financial and other information prior to soliciting donations in that state. ${ }^{6 y}$ The designated official is usually the Secretary of State or the Attorney General. ${ }^{70}$ Registration and reporting is a central function of

59 Model Act $\$ 11$ (cited in note 46).

60 Wilson, 12 Prob \& Prop at 53 (cited in note 36). See, for example, Mass Ann Laws ch 68, $\S 27$ (Law Co-op 1999), which allows the state charities division to "accept information filed by a charitable organization with the appropriate authority of another state or of the United States in lieu of the information required to be filed" in Massachusetts.

61 See Wilson, 12 Prob \& Prop at 53 (cited in note 36).

62 See <http://www.nonprofits.org/library/gov/urs/> (visited Mar 4, 2000).

63 Model Act $\$ 1(\mathrm{e})$ (cited in note 46).

64 See, for example, Alaska Stat $\S 45.68 .900(2)$ (1999), which defines "contributions" as "contributions of money or property."

65 Bograd, The Role of State Attorneys General at 24 (cited in note 32).

66 Wilson, 12 Prob \& Prop at 53 (cited in note 36).

67 Model Act $\$ 1(\mathrm{a})(1)-(2)$ (cited in note 46 ).

68 Wilson, 12 Prob \& Prop at 53 (cited in note 36 ).

69 See, for example, NY Executive Law $\$ 172$ (McKinney 1993 \& Supp 1999); Conn Gen Stat Ann § 21a-190b-c (West 1994).

70 See Bograd, The Role of State Attorneys General at 22-24 (cited in note 32). 
charity offices." A number of smaller municipal subdivisions, including cities and counties, have charitable solicitation statutes as well. ${ }^{2}$

Although the legal status of soliciting donations via a web page is uncertain, the consequences of soliciting in a state without meeting the state's registration and reporting requirements are clear and can be severe. States may be awarded civil penalties by a court of up to $\$ 10,000$ for each violation of their solicitation statutes. ${ }^{73}$ The Illinois Attorney General's office is suing a charity that solicited in-state monies without registering (and that used only $\$ 461$ of $\$ 205,031$ raised for charitable purposes) for $\$ 205,000$ in compensatory damages and $\$ 205,000$ in punitive damages. ${ }^{74}$ If an unregistered charity solicits in New York, the state may assess damages equal to the entire amount of funds solicited without an offset for fundraising expenses incurred by the charity. ${ }^{75}$ If a fundraiser uses unregistered solicitors, a jurisdiction may issue a temporary restraining order barring all solicitation by that fundraiser. ${ }^{76}$

\section{B. Federal Involvement}

While states remain responsible for most charitable regulation and policing fraud, the federal government plays a role as well through contribution incentives and required information disclosure. Beginning in 1942, Congress required tax-exempt organizations to file information disclosures with the Internal Revenue Service." Since 1996, Congress also has required tax-exempt groups to mail their exemption application (IRS Form 1023) and last three annual returns (IRS Form 990 or $990-\mathrm{PF}$ ) promptly to those who request it. ${ }^{\text {s8 }}$ A char-

72 See, for example, International Society for Krishna Consciousness of Houston, Inc v City of Houston, 689 F2d 541,543-44 (5th Cir 1982) (upholding the constitutionality of a typical city registration requirement); American Charities for Reasonable Fundraising Regulation, Inc v Pinellas County, 32 F Supp 2d 1308, 1311-12 (M D Fla 1998) (upholding county ordinance that required charities to register with the county, pay an application fee, maintain specific records, and comply with reporting requirements).

73 The state may also obtain an injunction, restitution, reasonable attorneys' fees, and costs of investigation and litigation. Model Act $\$ 17(\mathrm{e})$ (cited in note 46).

74 Maura Kelly, Little of Mission's Money Went to Homeless, Suit Says, Chi Trib 5 (Mar 8, 2000).

75 David G. Samuels, Registration of Charitable Groups and Fund Raisers, NY L J 1 (Aug 29, 1995), citing Abrams v Pacific West Cancer Fund, No 46578-88 (NY Sup Ct, NY County Dec 13, 1989).

76 Samuels, NY L J at 1 (cited in note 75), citing People v Upstate New York Veterans Outreach Association, No 13095-91 (NY Sup Ct, Monroe County June 22, 1995).

77 See Brody, 41 Vill $L$ Rev at 486 (cited in note 29).

78 See id; Gioia M. Ellingsworth and Lisa G. Horning, New Public Disclosure Rules Present Opportunities and Challenges to Exempt Organizations, 23 Exempt Org Tax Rev 55, 55-56 (1999) (detailing penalties for failure to comply). See IRC § 6104(d), codified at 26 USCA \$ 6104(d) (West Supp 1999).
} 
ity, however, need not provide the information if it is "widely available." Information from Form 990 is in the process of being posted on the web, which may trigger the "widely available" caveat per se." This may help increase the "visibility and scrutiny" of charitable activities. ${ }^{2}$ Form 990 and its accompanying Schedule A require the disclosure of extensive information on revenues, expenses, balance sheet accounts, professional fundraising fees, and compensation of employees and independent contractors. The Internal Revenue Code has the effect of regulating the form that many charitable organizations take. Moreover, while the Federal Trade Commission is not involved in general charitable oversight, it can pursue "charitable" violators of federal laws. The FTC has occasionally, in conjunction with state officials, sued charities accused of fraud and misrepresentation. ${ }^{86}$

There have been proposals in the past to expand the role of the federal government in the area of charities regulation. In 1977, the United States Treasury, under the leadership of John H. Filer, conducted a large-scale study of the nonprofit sector and recommended establishing a national supervisory agency. ${ }^{87}$ However, the Carter administration was not interested in establishing such an agency.

In the last decade, members of Congress have proposed bills to require exempt organizations to disclose the percentage of funds raised that are spent on exempt purposes, and have introduced bills to require professional fundraisers to reveal the percent of the money they collected that went to fundraising costs. ${ }^{\circledR 2}$ These were attempts to enact, through the Internal Revenue Code, the requirements in state

79 IRC \$ 6104(d)(4).

80 See <http://www.guidestar.org/news/features/990status.html> (visited Feb 12, 2000), which is in the process of posting information from Form 990 on its web site. Form 990 s for some organizations are currently available.

81 "Widely available" is not defined in the Code, but is expected to be defined through regulations. Ellingsworth and Horning, 23 Exempt Org Tax Rev at $56 \mathrm{n} 6$ (cited in note 78).

82 Id at 56.

83 Form 990-PF requires the disclosure of similar information for private foundations.

84 For example, the Code limits the nature of qualifying organizations, does not permit lobbying or participation in a political campaign, and does not allow net earnings to be distributed to private shareholders or individuals. IRC $\$ 501(\mathrm{c})(3)$. Further, the Code limits the terms on which charities may lend money, buy property, and pay compensation. IRC $\$ 503$ (b).

85 Federal Trade Commission, Facts for Consumers: Charitable Donation\$: Give or Take, available online at <http://www.ftc.gov/bcp/conline/pubs/tmarkg/charity.pdf (visited Mar 17, 2000).

86 For links to six cases, see <http:/www.ftc.gov/bcp/conline/edcams/giving/index.html> (visited Mar 17,2000).

87 Commission on Private Philanthropy and Public Needs, Commentary on Commission Recommendations, in 1 Filer Commission Research Papers at 38 (cited in note 19).

88 Peter Dobkin Hall, Inventing the Nonprofit Sector and Other Essays on Philanthropy, Voluntarism, and Nonprofit Organizations 78 (Johns Hopkins 1992).

89 See Espinoza, 64 S Cal L Rev at 672 \& n 317 (cited in note 19). 
solicitation statutes struck down by the Court in Riley. ${ }^{90}$ However, one commentator has argued that giving charitable oversight to tax authorities would "complicate regulation and undermine constitutional interests.",91

- In 1990, Representative Luken introduced a bill to authorize the FTC to regulate charitable fundraising. "The bill was referred to committee, but no further action was taken on it. While there have been recent proposals to amend the Internal Revenue Code as it relates to charities, ${ }^{93}$ there have not been recent attempts to expand federal government oversight of charities. Thus, the federal government's efforts toward regulating charitable institutions remain limited to those reflected in the Internal Revenue Code.

\section{THE INTERNET. JURISDICTION, DORMANT COMMERCE ClAUSE, AND FEDERAL POLICY}

The Internet has posed new and complex questions for lawmakers and the courts. There are approximately 101 million Internet users in the United States. It is difficult to determine the identity of a person accessing the Internet, ${ }^{95}$ although commentators have argued that improvements in technology may alleviate this problem. ${ }^{*}$ To date, there are no reported cases concerning online charitable solicitation and registration, although the issue is of great interest in the nonprofit community given the rapid spread of web-based fundraising.

90 See text accompanying notes 54-58.

91 Espinoza, $64 \mathrm{~S}$ Cal L Rev at 673 (cited in note 19).

92 Fair Fundraising Act of 1990, HR 3964, 101st Cong, 2d Sess (Feb 6, 1990), in 136 Cong Rec H 298 (Feb 6, 1990).

93 See, for example, Religious Liberty and Charitable Donation Protection Act of 1997, HR 2604, 105th Cong, 2d Sess (Oct 2, 1997), in 143 Cong Rec H 8320 (Oct.3,1997); Charity Empowerment Act of 1999, S 997, 106th Cong, 1st Sess (May 11, 1999), in 145 Cong Rec S 5036 (May 11, 1999).

94 Leslie Cauley, William Boston, and Gautam Naik, Deutsche Telekom Sets $\$ 3$ Billion Cable Deal, Wall St J A21 (Feb 22, 2000).

95 See Reno v $A C L U, 521$ US 844, 855-56 \& n 20 (1997). "No single organization controls any membership in the Web, nor is there any centralized point from which individual Web sites or services can be blocked from the Web." Id at 853 .

96 See Goldsmith, $65 \mathrm{U}$ Chi L Rev at 1218, 1227 (cited in note 20) (noting that Internet providers can already achieve significant control over information flows, and advances in filtering and identification technology promise to improve this).

97 For example, there are now multiple books available instructing nonprofits on how best to use the web for fundraising. See, for example, Michael W. Johnston, The Nonprofit Guide to the Internet: How to Survive and Thrive (Wiley 2d ed 1999); Gary B. Grant, The Wilder Nonprofit Field Guide to Fundraising on the Internet (Amherst H. Wilder Foundation 1999). Additionally, an online list-serv devoted to accountability issues for nonprofits using electronic communications has generated much discussion on this topic. See <http://www.bway.net/ hbograd/cybacc.html > (visited Mar 18,2000) (containing a link to archives of such discussions). 
This Part will first address the courts' treatment of the assertion of personal jurisdiction based on Internet contacts in the forum state. Under the traditional tests for personal jurisdiction, it seems likely that an active online solicitation will subject the solicitor to personal jurisdiction. This Part will then address the dormant Commerce Clause concerns. While the dormant Commerce Clause applies to nonprofit organizations, the courts have routinely upheld solicitation statutes despite dormant Commerce Clause challenges. Further, while the dormant Commerce Clause applies to the Internet, this does not imply that states have no authority to regulate Internet activities. Finally, this Part notes that while the federal government has evinced some intent to regulate the Internet exclusively, this intent remains controversial and undecided. States should (and can) legally apply their solicitation (and other) existing laws to the Internet in order to protect their legitimate interests and those of their citizens.

\section{A. Personal Jurisdiction}

In order for a state to enforce its laws against online solicitors who do not register, it must be able to obtain jurisdiction over them. ${ }^{98}$ While the courts' decisions in this area have not been completely consistent, in all likelihood a state would be able to obtain jurisdiction over online solicitors. ${ }^{99}$ Under International Shoe $v$ Washington, ${ }^{100}$ for a forum to exercise jurisdiction over a defendant, the defendant must have "minimum contacts" with the forum state such that exercising jurisdiction would not offend "traditional notions of fair play and substantial justice., ${ }^{101}$ The Court has elaborated on the personal jurisdiction inquiry further in recent years. Under the purposeful availment test first laid out in Asahi Metal Industries v Superior Court, ${ }^{102}$ a threshold inquiry in the determination of personal jurisdiction is whether the defendant has purposefully availed him or herself of the forum state. $^{103}$

98 Goldsmith, 65 U Chi L Rev at 1216-17 (cited in note 20) (noting that a state can only regulate activity insofar as it can enforce its laws, and that it can only enforce its laws against an entity with no local presence if it can obtain personal jurisdiction over the entity and get a default judgment).

99 "Active" solicitors here refers to web sites that specifically request contributions. Web sites that are simply informational or are advertisements may fall under a different rubric. See the discussion in this Part.

100326 US 310 (1945).

101 Id at 316.

102480 US 102, 108-09 (1987). Although only a plurality supported the Asahi holding, the Court later affirmed the use of this test in Burger King Corp v Rudzewicz, 471 US 462, 472-75 (1985).

103 Asahi, 480 US at 108-09; Burger King, 471 US at 472. 
Courts $^{104}$ and commentators ${ }^{105}$ frequently have addressed the issue of whether an individual or organization whose only contact with the forum state is a web site nevertheless may be subject to personal jurisdiction there. Courts have applied the personal jurisdiction tests to Internet-only contacts with varying results. In a number of cases, courts have found personal jurisdiction over defendants based on the simple fact that the defendants' web sites were accessed in the forum state. $^{106}$ Other courts have found personal jurisdiction to lie when the defendants sell a product over the Internet that individuals purchase in the forum state. ${ }^{107}$ Knowingly advertising on a web site and receiving publicity and contributions as a result may qualify as purposeful availment under the Asahi test, subjecting one to the court's jurisdiction. ${ }^{108}$ However, if items are not available for purchase in the forum state from the web site then jurisdiction may not be proper. ${ }^{100}$

Despite some of the preceding cases, most courts adjudicating the issue of personal jurisdiction have required something more than the mere accessibility of a web site in the forum state to assert personal jurisdiction. ${ }^{110} \mathrm{~A}$ web site that actively solicits donations, rather than passively exists as an informational site, seems likely to cross this threshold, and to provide the minimum contacts sufficient to support

104 See notes 106-109.

105 See Jack L. Goldsmith, The Internet and the Abiding Significance of Territorial Sovereignty, 5 Ind J Global Legal Stud 475, 485-86 (1998) (casting doubt on the idea that a web site alone could give rise to personal jurisdiction); Lori Irish Bauman, Personal Jurisdiction and Internet Advertising, 14 Computer Law 1 (Jan 1997) (analyzing cases upholding personal jurisdiction claims based on web sites); Charles H. Fleischer, Will the Internet Abrogate Territorial Limits on Personal Jurisdiction?, 33 Tort \& Ins L J 107 (1997) (contending that a web site should not subject site owners to personal jurisdiction); Stephen Wilske and Teresa Schiller, International Jurisdiction in Cyberspace: Which States May Regulate the Internet?, 50 Fed Commun L J 117 (1997) (discussing different potential jurisdictional restrictions on state regulation).

106 Maritz, Inc v CyberGold, Inc, 947 F Supp 1328, 1333-34 (E D Mo 1996) (having a web site that infringes a trademark is equivalent to committing a tortious act in the forum state, which is a basis for jurisdiction under state law); Inset Systems, Inc v Instruction Set, Inc, 937 F Supp 161, 164 (D Conn 1996) (having a web site that is continuously available to Connecticut's 10,000 Internet access sites meets the requirements of Connecticut's long-arm statute, which allows for jurisdiction over claims arising from business solicited in the state if the company has repeatedly solicited business in the state).

107 See Zippo Manufacturing Co v Zippo Dot Com, Inc, 952 F Supp 1119, 1126-27 (W D Pa 1997) (selling passwords to 3,000 Pennsylvania subscribers constitutes purposeful availment).

108 Heroes, Inc v Heroes Foundation, 958 F Supp 1, 3 (D DC 1996) (finding that web page solicitation combined with newspaper advertisement created minimum contacts with the District of Columbia).

109 Bensusan Restaurant Corp v King, 937 F Supp 295, 299 (S D NY 1996) (holding that web page that allegedly infringed on a trademark did not amount to committing a tortious act in the forum state and was not an act directed purposefully toward the forum state); Hearst Corp v Goldberger, 1997 US Dist LEXIS 2065, *1 (S D NY 1997) (finding no jurisdiction over web site owner in trademark infringement suit who had not contracted to sell or actually sold any goods or service in the forum state).

110 See Goldsmith, 5 Ind J Global Legal Stud at 486 (cited in note 105). 
personal jurisdiction. For example, in Heroes, Inc v Heroes Foundation, ${ }^{111}$ Heroes, Inc., a charitable organization, brought a trademark infringement action against Heroes Foundation, another charity that had allegedly infringed its trademark in HEROES and an accompanying design. ${ }^{122}$ The mark appeared on the defendant's web site and in an advertisement that the defendant placed in the Washington Post. ${ }^{113}$ The court found jurisdiction based on the newspaper ad and did not reach the issue of whether the home page alone would subject the defendant to jurisdiction. ${ }^{114}$ The court did lend importance to this contact with the District of Columbia, and in particular to the fact that "the defendant's home page explicitly solicits contributions."

Jurisdiction over a soliciting web site may be proper on other bases as well. As one court acknowledged, having a web site (whether it raises money or not) may be analogous to having an ad in a national magazine. ${ }^{116}$ In this instance, the court found that exercising jurisdiction solely on this basis would violate the Due Process Clause of the Fourteenth Amendment and the standards set out in International Shoe. Nevertheless, the court explicitly acknowledged that personal jurisdiction might be established in those instances where a defendant actually does business on the Internet or where the user can exchange information with the host web site. ${ }^{17}$ This analysis finds support in Supreme Court precedent, as the Court has found that regular circulation of a magazine in the forum state provides jurisdiction in a libel action based on the magazine's content. ${ }^{118}$ Similarly, because web sites are regularly available to residents in all states, courts could support personal jurisdiction based on web site accessibility.

\section{B. Dormant Commerce Clause and State Regulation}

State regulation of charities and Internet transactions implicates the dormant Commerce Clause. However, courts have upheld the application of solicitation statutes in "real space" against dormant

111958 F Supp 1 (D DC 1996).

112 Id at 2.

113 Id at $3-4$.

114 Id at 4.

115 Id.

116 See Weber $v$ Jolly Hotels, 977 F Supp 327, 333 (D NJ 1997) (finding that advertising through a web site did not give the court personal jurisdiction).

117 Id.

118 Keeton v Hustler Magazine, Inc, 465 US 770, 773-74 (1984). While one lower court has distinguished this case, Supreme Court precedent still clearly controls. See McDonough v Fallon McElligot Inc, 40 USPQ2d 1826, 1828-29 (S D Cal 1996) (distinguishing Keeton on the basis that Keeton involved specific jurisdiction while $M c D o n o u g h$ involved general jurisdiction and rejecting notion that having a web site that is used by the forum's residents could subject the site owner to personal jurisdiction in the forum). 
Commerce Clause challenges. Thus, although courts have yet to apply existing state regulations to the Internet, states should be able to regulate online solicitations without violating the dormant Commerce Clause.

\section{Overview of the dormant Commerce Clause.}

The Commerce Clause states that Congress has the power "[t]o regulate Commerce ... among the several States ...." Congress has the affirmative power to enact regulations affecting interstate commerce. ${ }^{120}$ Even in the absence of congressional action, the Supreme Court has found that states may not enact statutes that discriminate against or unduly burden interstate commerce. ${ }^{121}$ The courts have recognized this "negative" or "dormant" aspect of the Commerce Clause for almost a century and a half. ${ }^{122}$

Generally, state statutes may implicate the dormant Commerce Clause in one of two ways. First, statutes that directly regulate or discriminate against interstate commerce are unconstitutional. ${ }^{123}$ Second, under Pike $v$ Bruce Church, Inc, ${ }^{124}$ if a facially neutral state statute "regulates evenhandedly to effectuate a legitimate local public interest, and its effects on interstate commerce are only incidental, it will be upheld unless the burden imposed on such commerce is clearly excessive in relation to the putative local benefits." Clause seeks to avoid inconsistent and overlapping state regulation, as well as economic protectionism by the states.

2. Dormant Commerce Clause and state regulation of charities in "real space."

The Supreme Court has found that both the Commerce Clause and the dormant Commerce Clause apply to nonprofit transactions. ${ }^{12}$

119 US Const Art I, \$ 8, cl 3 .

120 See Quill Corp v North Dakota, 504 US 298, 309 (1992), citing Gibbons v Ogden, 22 US (9 Wheat) 1,31-32,39 (1824).

121 See New Energy Co of Indiana v Limbach, 486 US 269,273-274 (1988).

122 See CTS Corp v Dynamics Corp of America, 481 US 69, 87 (1987), citing Cooley v Board of Wardens, 53 US (12 How) 299 (1852).

123 See American Charities for Reasonable Fundraising Regulation, Inc v Pinellas County, 32 F Supp 2d 1308, 1315 (M D Fla 1998) (concluding that county registration statute did not directly regulate interstate commerce), citing Healy $v$ Beer Institute, 491 US 324, 336 (1989), Brown-Forman Distillers Corp y New York State Liquor Authority, 476 US 573, 579 (1986), and Edgar v MITE Corp, 457 US 624, 642 (1982) (plurality).

124397 US 137 (1970).

125 Id at 142.

126 See Healy, 491 US at 336-37; Brown-Forman, 476 US at 583-84.

127 See Camps Newfound/Owatonna, Inc v Town of Harrison, 520 US 564, 584 (1997) ("We see no reason why the nonprofit character of an enterprise should exclude it from the coverage of either the affirmative or the negative aspect of the Commerce Clause."). The Court found that 
Accordingly, courts frequently have applied laws that regulate commerce to nonprofit organizations."

While state regulation of out-of-state solicitors does result in multiple jurisdictions regulating one charity, courts have found that solicitation ordinances themselves do not violate the Commerce Clause for several reasons. First, they do not regulate interstate commerce wholly outside the state. Second, they relate to legitimate government interests in protecting the public from fraud. Third, they are not unduly burdensome in relation to their putative local benefits. ${ }^{129}$ The Supreme Court has reaffirmed that while solicitation is protected under the First Amendment, states do have a legitimate interest in regulating charities to protect both the charities and the public from fraud as long as the regulation is narrowly tailored. ${ }^{1.0}$ Various solicitation statutes have survived Due Process and First Amendment challenges.

When a state applies its registration requirements to an out-ofstate charity in the same way that it applies them to an in-state charity, this does not raise the discriminatory concerns that are a central feature of dormant Commerce Clause jurisprudence. ${ }^{132}$ Given the facial neutrality of most solicitation statutes, they should be analyzed under the $P i k e^{133}$ balancing test laid out at the beginning of this Part. ${ }^{1.4}$ In the state-to-state context, given that not all states regulate fundraising (though most do), there may be a concern that this places an undue burden on charities in nonregulating states. However, the concerns are the same as those that exist in real space.

\section{Dormant Commerce Clause and the Internet.}

Unsurprisingly, courts have found that the dormant Commerce Clause applies to the Internet. The Internet, like a highway or rail-

Maine law, which provided favorable tax treatment to charities that primarily benefited in-state residents would have clearly violated the dormant Commerce Clause if the law applied to forprofit entities as well as to nonprofit entities.

128 See id at 583-84 (listing cases).

129 See American Charities for Reasonable Fundraising Regulation, Inc v Pinellas County, 32 F Supp 2d 1308, 1315-17 (M D Fla 1998) (upholding county registration requirement); American Target Advertising, Inc y Giani, 23 F Supp 2d 1303, 1309-11 (D Utah 1998), revd on other grounds, 199 F3d 1241 (10th Cir 2000) (striking portions of law on First Amendment grounds while affirming dismissal of Commerce Clause claims).

130 See Riley, 487 US at 788,792 .

131 American Charities, 32 F Supp 2d at 1321, 1327-28 (involving facial Due Process and First Amendment challenge).

132 Camps Newfound/Owatonna, 520 US at 581 ("[D]iscrimination [against out-of-state consumers] is at the very core of activities forbidden by the dormant commerce clause.").

133 See text accompanying notes 124-25.

134 See American Charities, 32 F Supp 2d at 1315-17 (upholding a solicitation ordinance after applying the Pike test). 
road, may be an instrument of interstate commerce and analyzed accordingly. ${ }^{135}$ Courts have found that Internet communications, in particular electronically mailed images via the Internet, constitute interstate commerce. ${ }^{136}$ Courts have invalidated state provisions explicitly aimed at regulating content on the Internet. ${ }^{137}$

\section{State laws and the Internet.}

At least thirteen states have passed new statutes regulating the Internet. ${ }^{133}$ These have mainly aimed at content on the Internet, although some have been tax bills. ${ }^{139}$ Some attorneys general, such as Mike Hatch of Minnesota, have actively pursued what they consider to be online violations of state law. ${ }^{140}$

However, while the Internet is a new medium, many existing state laws still apply. Advertising laws, both state and federal, apply to ads on the Internet. ${ }^{141}$ State common law principles, such as trespass to chattels, similarly apply to the Internet. ${ }^{14}$

States should equally be able to apply their solicitation laws online. Protection of consumers from fraud, the aim of solicitation statutes, falls under state police powers and is a compelling local. interest. ${ }^{143}$ The possibilities for fraud are multiplied on the Internet-it is inexpensive to establish a web page and is easy to reach a vast audi-

135 American Libraries Association v Pataki, 969 F Supp 160, 161 (S D NY 1997).

136 In United States $v$ Thomas, 74 F3d 701 (6th Cir 1996), cert denied, 519 US 820 (1996), the court held that defendants who operated a subscription-only computer bulletin board from California with obscene images were subject to jurisdiction in Tennessee when an undercover government agent subscribed and accessed the bulletin board from Tennessee. Id at 706-09. The mailing of obscene images constituted interstate commerce under 18 USC $\$ 1465$, which prohibits transportation of obscene materials in interstate commerce. Id.

137 See, for example, $A C L U$ v Johnson, 194 F3d 1149 (10th Cir 1999), which invalidated a New Mexico law criminalizing dissemination by computer of material harmful to minors, in part on Commerce Clause grounds.

138 See Christopher S.W. Blake, Note, Destination Unknown: Does the Internet's Lack of Physical Situs Preclude State and Federal Attempts to Regulate It?, 46 Cleve St L Rev 129, 138 (1998).

139 See id. The federal Internet Tax Freedom Act has placed a moratorium on any new bills taxing the internet. See discussion in Part II.C.

140 See Burk, 28 Conn L Rev at 1096 (cited in note 14).

141 David M. Eisenberg, Questions and Answers About Advertising on the Internet, 43 Prac Law 79, 80 (July 1997).

142 See America Online, Inc v IMS, 24 F Supp 2d 548, 549-51 (E D Va 1998) (finding the defendant, whose principal place of business was in California, guilty of trespass to chattels under Virginia common law, based on mailing of unsolicited email messages whose origin was disguised to subscribers of plaintiff, an Internet service provider located in the Eastern District of Virginia). See also CompuServe Inc v Cyber Promotions, Inc, 962 F Supp 1015, 1017 (S D Ohio 1997) (finding valid a state law prohibiting trespass to personal property in a claim based on similar facts).

143 See Citizens for a Better Government, 444 US at 636 (stating that the Village did have an interest in preventing fraud, but that the statute in this instance did not protect that interest). 
ence. While state regulation of Internet solicitation implicates the dormant Commerce Clause, such regulation does not violate it and remains justified by important state interests.

\section{Federal Assertion of Control over the Internet?}

Both Congress and the President have evinced an intent to control certain aspects of the Internet on a national, rather than a state, level. ${ }^{144}$ While this indicates that federal regulation may replace state regulatory efforts directed toward the Internet, this is by no means clear. For example, the Communications Decency Act of 1996 sought to regulate pornography on the Internet and to limit the access of minors to such information. ${ }^{145}$ Although the Supreme Court struck down provisions of the Act that prohibited knowing transmittal of obscene, indecent, patently offensive, or sexual images or descriptions to minors as violative of First Amendment free speech rights, ${ }^{14}$ the Court did leave open the possibility of future Internet regulation. ${ }^{147}$ Further, the Internet Tax Freedom Act ("ITFA") has placed a moratorium until October of 2001 on new discriminatory state sales taxes on e-commerce and the levying of new Internet access taxes. ${ }^{148}$ Significantly, the ITFA "prohibits state and local governments from requiring remote electronic merchants to collect sales tax based solely on the ability of a consumer to access that merchant's computer server" and "prevents states from imposing taxes solely because a remote seller displays content on or processes orders through an Internet service provider's out-of-state computer server."149

The ITFA has been highly controversial. State and local officials remain greatly concerned that the Act will become permanent, resulting in a loss of revenues. ${ }^{150}$ Advocates of e-commerce feel that an electronic tax will burden online transactions, discourage e-consumers,

144 See Blake, Note, 46 Cleve St L Rev at 149 (cited in note 138).

145 Communications Decency Act of 1996, Pub L No 104-104, 110 Stat 133 (1996), codified at 47 USC $\$ 223$ (Supp 1996).

146 Reno v $A C L U, 521$ US 844, 859-60,874-79 (1997) (striking down Act as vague and overbroad).

147 Id at 863 n 30 ("According to [the District Judge], [the Internet's] characteristics and the rest of the District Court's findings 'lead to the conclusion that Congress may not regulate indecency on the Internet at all.' Because [plaintiffs] do not press this argument before this Court, we do not consider it. [Plaintiffs] also do not dispute that the Government generally has a compelling interest in protecting minors from 'indecent' and 'patently offensive' speech.") (citation omitted). 1998).

148 Internet Tax Freedom Act, Pub L No 105-277, Title XI, codified at 47 USCA $§ 151$ (West

149 Lisa I. Fried, Internet Taxation: An Advisory Committee Is Embroiled in Debate, NY L J 5 (Sept 23, 1999).

150 Id. 
and violate the Commerce Clause. ${ }^{\text {ist }}$ However, the Advisory Commission on Electronic Commerce has noted the need to "be respectful of sovereignty of state and local jurisdictions." ${ }^{\text {t52 }}$ While Congress has addressed taxes and indecent content on the Internet, it has not passed legislation providing for comprehensive federal control of the Internet. It has not addressed many aspects of the Internet, including solicitation laws. Thus, there has been no preemption of state solicitation laws as applied to the Internet.

Some courts have described the Internet as an instrument of interstate commerce that should be subject to exclusive federal oversight. ${ }^{133}$ In the past, other new technologies that transcended geographical boundaries have confronted the Court. The Court initially saw such technologies as "instruments" of commerce and struck down regulation by the states; however, the Court later backpedaled and upheld state regulation. ${ }^{1.4}$ Further, as noted previously in this Part, other courts have applied existing state laws to the Internet. There is not currently exclusive federal control in this area, and it remains unclear what direction it will take.

\section{SUPPORT FOR STATE REGULATION}

While some commentators have argued that the Internet cannot be regulated at all, this argument has serious flaws. This Part notes that Internet communications involve real people and that the concerns that motivate regulation in real space are just as valid in cyberspace. Further, this Part argues that allowing the federal government to regulate Internet solicitations would expand the federal government's role in all charitable oversight, either through duplicating state efforts or through preempting state regulation. Duplication is administratively burdensome and unnecessary. Preemption is undesirable, as the protection of consumers from fraud that motivates solicitation laws is a state police power and is closer to the heart of state, rather than federal, government concerns.

151 Id.

152 Advisory Commission on Electronic Commerce, Issues and Policy Options Paper: Final Draft Submitted to the Commission from the Report Drafting Subcommittee, 12-3-99, available online at <http//:www.ecommerce.commission.org/document/issuesPO.pdf (visited Mar 6, 2000).

153 See, for example, American Libraries Association v Pataki, 969 F Supp 160, 182 (S D NY 1997) ("The Internet, like [ ] rail and highway traffic ... requires a cohesive national scheme of regulation so that users are reasonably able to determine their obligations."); $A C L U v$ Johnson, 194 F3d 1149, 1162 (10th Cir 1999) ("[C]ertain types of commerce have been recognized as requiring national regulation.... The Internet is surely such a medium.").

154 See James E. Gaylord, Note, State Regulatory Jurisdiction and the Internet: Letting the Dormant Commerce Clause Lie, 52 Vand L Rev 1095, 1117-21 (1999) (describing the history of the Court's treatment of the telegraph). 


\section{A. Arguments against a Complete Lack of Public Regulation}

Some commentators have argued that the absence of traditional geographic boundaries in cyberspace indicates that it is impossible for states to apply territorially based notions of the law to the Internet and that states should instead defer to self-regulation online. ${ }^{\text {iss }}$ However, the Internet still involves "people in real space in one jurisdiction communicat[ing] with people in real space in another jurisdiction." ${ }^{156}$ There is a need for public regulation of the Internet in addition to private ordering. ${ }^{15}$ Absent public ordering, private ordering may arise that is inefficient and not in the public interest.

States' concerns about fraud being perpetrated against their citizens are no less legitimate in the Internet context than in real space. Such concerns may be even greater online given the low start-up costs and the broad audience that a solicitation may reach. Despite concerns about the difficulty of locating users geographically on the Internet, it is "feasible and constitutional" for the law to require the altering of the Internet's code to enable identification of users by various criteria, ${ }^{1,8}$ which could include geographic locale.

\section{B. Arguments against Federal Regulation of Online Solicitation}

Allowing federal regulation of Internet solicitations would likely mean expanding the overall federal role in the oversight of charities. Efforts in the past to expand the federal role in this area have proven unsuccessful. ${ }^{\text {s5 }}$ The IRS is the only government agency that collects information on charities. Expanding the role of the IRS in charitable oversight is undesirable. As one commentator notes: "Moving the oversight of charity to tax authorities will complicate regulation and undermine the protection of constitutional interests." mentators have criticized efforts to establish a uniform federal charities law, arguing that there is no similar provision or proposal for forprofit corporations. ${ }^{165}$

Regulation of solicitation would require the federal government to register charitable solicitors, monitor their solicitations, and track down and punish violators. It would be duplicative and unnecessarily

155 Johnson and Post, 48 Stan L Rev at 1367 (cited in note 21).

156 Goldsmith, 5 Ind J Global Legal Stud at 476 (cited in note 105).

157 Goldsmith, $65 \mathrm{U}$ Chi L Rev at 1213-16 (cited in note 20) (discussing possible usage of public laws to supplement private ordering).

158 See Lessig, 113 Harv L Rev at 515-18 (cited in note 20). While doing so could raise serious privacy concerns, the government could also "subsidize architectures for privacy" on the Internet in order to address this. Id at 544.

159 See discussion in Part I.B.

160 Espinoza, 64 S Cal L Rev at 673 (cited in note 19).

161 See, for example, Brody, 41 Vill L Rev at 497 (cited in note 29). 
costly for both the state and federal government to do so. The interests in each case (protection of consumers from fraud) remain the same. Nothing would be added by federal regulation. Although there have been past (unsuccessful) recommendations for the federal government to regulate charitable solicitation, at least some of the conditions that prompted these recommendations have changed. ${ }^{162}$

It is also undesirable for federal regulation to preempt state regulation. It is a well established principle that state police powers encompass the protection of citizens from fraud. ${ }^{163}$ There is no general federal police power. ${ }^{164}$ While the federal government can regulate interstate commerce, and nonprofit transactions fall under this power, state solicitation and registration statutes still pass the Pike balancing test. $^{165}$ Thus, state interests in protecting against fraud can outweigh burdens on interstate commerce.

The FTC already has authority over unfair and deceptive trade practices involving interstate commerce. ${ }^{166}$ While this does not generally include authority over nonprofits, it can on an ad hoc basis. ${ }^{167}$ Federal interests in consumer protection may thus be taken into account in ways other than requiring federal registration of charitable solicitors.

While the federal government has evinced some intent to control the Internet on a national level, it has never set up a national supervisory or regulatory agency. And, as one commentator notes: "There are few who believe that another agency with additional resources is a sufficient cure for any social ill."

Some courts have found that the Internet is an instrument of interstate commerce, and as such should be subject exclusively to federal control. ${ }^{169}$ These cases have struck down new laws that were aimed

162 See Commission on Private Philanthropy and Public Needs, Giving in America: Toward a Stronger Voluntary Sector 177 (Treasury Dept 1975). The Commission recommended federal regulation of charitable solicitation, noting that only twenty-five states regulated solicitations and that the coverage and scope of the laws varied widely. However, today nearly forty states regulate solicitation, and the laws are more comprehensive and uniform due to the Model Act.

163 Don F. Vacarro, Validity and Application of Governmental Limitation on Permissible Amount or Proportion of Fundraising Expenses or Administrative Costs of Charitable Organizations, 15 ALR 4th 1163 (1982).

164 Larry McInnis, The Municipal Management of Emergencies: The Houston Plan, 4 Tex Forum on Civ Lib \& Civ Rts 139, 143 (1999).

165 See text accompanying notes 124-25.

166 See 15 USC § 45 (1994).

167 William Meade Fletcher, 10A Fletcher Cyclopedia of Private Corporations $\S 4984$ (West 1999).

168 Fishman, 34 Emory L J at 671 (cited in note 26) (referring specifically to the case of nonprofit corporations).

169 See $A C L U$ v Johnson, 194 F3d 1149, 1160-63 (10th Cir 1999) (striking down New Mexico statute that criminalized dissemination of material harmful to minors by computer as violative of the First Amendment and the Commerce Clause); American Libraries Association $v$ 
specifically at the Internet. However, the courts have upheld the application of existing state laws to the Internet. ${ }^{120}$ Arguments that the Internet is national in nature can just as easily be countered by arguments that the Internet is international in nature, and that the United States government should not be able to regulate it either. We are then left with a regime of no regulation, which is unacceptable. ${ }^{17}$ Given the broad definition of solicitation and the fact that solicitations can be deemed to occur where they are received, existing state laws can easily encompass Internet solicitation.

Similarly, in cases of gambling on the Internet, courts have found the gambling to occur where the bet is placed rather than where the web site is hosted, and to be illegal under state law. ${ }^{12}$ The Internet's status as a new medium does not alter the basic features of a solicitation: a request by a real-space organization for money that is received by a real-space state resident.

This Part does not argue that there should be no national policy or regulation of the Internet. However, the arguments for state regulation of solicitation remain as strong in cyberspace as they are in real space, and there is no good reason for the federal government to abrogate this or the many other state consumer protection (and criminal) laws that should legitimately apply online.

\section{Arguments for State Regulation}

It is entirely logical and desirable for states to apply their laws as described above. An individual prohibited from committing trespass to chattels (or violations of other state common or statutory laws) in real space should not be able to evade the law by using the Internet. Although the Internet may be an instrument of interstate commerce, this does not imply that the federal government can or should preempt all state laws that might apply. Both state and federal governments have applied their existing laws to gambling on the Internet in order to protect their legitimate interests. ${ }^{13}$ There is no indication that federal law will preempt state law in the online gambling context. In fact, "in no case does an activity characterized by a state interest become an activity devoid of state interest simply because it has been re-

\footnotetext{
Pataki, 969 F Supp 160, 161 (S D NY 1997) (striking down similar New York statute on Commerce Clause grounds).

170 See note 142 and accompanying text.

171 See discussion in Part III.A.

172 People $v$ World Interactive Gaming Corp, 1999 NY Misc LEXIS 425, *1-2, *4-5 (NY Sup Ct July 22,1999).

173 For a general discussion of the application of state and federal gambling laws to the Internet, see Michael Schwartz, The Internet Gambling Fallacy Craps Out, 14 Berkeley Tech L J 1021 (1999).
} 
located to cyberspace." ${ }^{\text {174 }}$ We live under a federal government of limited powers: "The powers delegated by the [ ] Constitution to the federal government are few and defined. Those which ... remain in the state governments are numerous and indefinite." ${ }^{175}$ Despite broad readings of the Commerce Clause power in the past, the Court has recently indicated that in some instances Congress may go too far. ${ }^{176}$ While there are concerns that state regulation of Internet solicitation (and Internet communications in general) may lead to overlapping and thus burdensome regulation, "we already live in a world of multiple, overlapping, contradictory, and oftentimes contested sovereignties." "While the Internet may complicate this, we already deal with the problem in real space and can do so in cyberspace.

While the federal government also has an interest in protecting United States citizens from fraud, state governments are by nature smaller and closer to their citizens, and thus have a more particularized interest in this area. State police powers are broad, ${ }^{178}$ while the federal government's police powers are narrow. ${ }^{179}$ States should be able to retain their police powers in cyberspace.

One of the principal concerns with the Internet is that entities cannot limit where their cyber-information is accessed, and thus cannot array their conduct in order to avoid regulation. However, online solicitors know (or hope) that they will obtain the benefits of raising money in any jurisdiction. Correspondingly, they know that there are burdens that accompany solicitation, given that almost all states require registration. If an organization obtains the benefits of contacts with residents of the forum state, then it should have to bear the bur-

174 Steven R. Salbu, Who Should Govern the Internet?: Monitoring and Supporting a New Frontier, 11 Harv J L \& Tech 429, 451 (1998) (stating that while some state interests may be reduced in cyberspace, calling for some federal preemption, states should be able to regulate particular areas).

175 United States $v$ Lopez, 514 US 549, 552 (1995) (striking down the Gun Free School Zones Act as beyond Congress's powers), citing Federalist 45 (Madison), in Clinton Rossiter, ed, The Federalist Papers 292 (Mentor 1961).

176 Lopez, 514 US at 552.

177 Keith Aoki, Considering Multiple and Overlapping Sovereignties: Liberalism, Libertarianism, National Sovereignty, "Global" Intellectual Property, and the Internet, 5 Ind J Global Legal Stud 443, 443 (1998).

178 The Tenth Amendment reserves to the states all powers not expressly delegated to the federal government. US Const Amend X. "[L]ocal governments are best able to monitor exempt organizations to ensure that they provide a public benefit," as they are closer to their citizens and citizens' interests. Developments in the Law: Nonprofit Corporations, 105 Harv L Rev 1578, 1626 (1992).

179 See Part III.B.

180 Gaylord, Note, 52 Vand L Rev at 1095 (cited in note 154) (arguing that states should be able to do so, and that the Court's concerns with the extraterritorial effects of state regulation under the dormant Commerce Clause are more properly seen as "nexus" concerns). 
dens as well. ${ }^{181}$ State regulation can be seen as a cost of doing business and obtaining benefits from the forum state, as well as a driving force behind the development of filtering technology. ${ }^{132}$ Further, internet communications are transmitted via telephone and cable lines. States can already regulate solicitations that reach their state via these means.

Professor Steven Salbu has argued that the characteristics of the Internet only require uniform (federal) control if they meet the following three criteria: (1) technological considerations requiring the compatibility of technologies; (2) the likelihood of serious Internet encumbrance through fractionalized regulation; and (3) the need for unified federal technologies to support federal policy goals and programs. ${ }^{1 / 3}$ State regulation of online solicitation would have no impact on the compatibility of technologies. Further, regulation is not likely to be fractionalized as states are already quite uniform in their charitable solicitation and reporting requirements. Finally, while the federal government collects information on charities for the purpose of tax exemption, there is no federal program as such implicated here. The federal policies of encouraging charitable deductions, ensuring that only legitimate charities receive exemptions, and requiring financial information to facilitate this will not be implicated by state regulation here.

State regulation meets two further standards articulated by Salbu: Internet technology leaves traditional state concerns (such as fraud) intact, and abandonment of local police power could create a serious enforcement gap. ${ }^{184}$ In order to facilitate state regulation, states can develop model codes relating to the Internet. ${ }^{\text {tos }}$ The Model Solicitation Act already in existence could aid such efforts.

Of the thirty-eight states and the District of Columbia that require registration, thirty-two states and the District of Columbia already use the uniform registration form developed by NAAG and NASCO. ${ }^{186}$ Requiring charities to register in all states where their web site is available would not be unduly burdensome, given this shared

181 Goldsmith, 5 Ind J Global Legal Stud at 485 (cited in note 105) ("From the perspective of the regulating jurisdiction, the content provider is knowingly sending information into a jurisdiction; like all persons who do the same in real space, the content provider benefits from this instate activity, is deemed to know the law of the territory, and is subject to penalties for noncompliance (assuming that enforcement is possible).").

182 Id at 489-90 (arguing that states should be able to force a service provider to comply with state gambling laws).

183 Salbu, 11 Harv J L \& Tech at 465-70 (cited in note 174).

184 Id at $470-71$.

185 Id at 478.

186 <http://www.nonprofits.org/library/gov/urs/o_appndx.htm\#alabama> (visited Apr 3, 2000). 
registration form. Moreover, it would provide significant local benefits in terms of availability of information to the public and oversight of potential fraud. State interests in preventing fraud do not simply disappear because a transaction occurs over the Internet. The main arguments against state regulation-that it is technologically difficult, potentially burdensome, or unconstitutional-do not hold water.

\section{PROPOSALS}

While state regulation of charitable solicitation is preferable to federal regulation, current state regulation is less than perfect. At least one writer has alleged that "[a]ll commentators on the subject agree that there is inadequate supervision of nonprofit corporations." There have been proposals at the state level to establish a formal "stakeholder" provision with regard to nonprofits, and to grant these stakeholders the rights to sue nonprofits, to access information about nonprofits, and to elect the board of directors or trustees. ${ }^{188}$ However, others note that granting members of the public the right to sue would generate excess litigation and would create a large, shifting, and uncertain group of plaintiffs. ${ }^{189}$ There have been other proposals to create both state and federal charities boards, but "[ $\mathrm{t}]$ he hard reality is that governments do not want to take over the business of running charities." 190

The Internet does require changes in the way that states currently regulate solicitation in order to make Internet regulation administratively feasible and minimally burdensome. A number of states have already adopted the Model Act's provision that allows for acceptance of a copy of a filing in another state in lieu of a separate filing. ${ }^{191}$ Most states use the uniform registration form developed by NAAG and NASCO. ${ }^{192}$ Charities can easily determine which states demand registration and what the registration requirements are through the non-

187 Fishman, 34 Emory L J at 668 (cited in note 26).

188 Stakeholders would include consumers, donors, and sponsors. This policy would be effected mainly by state-level Offices for Nonprofit Organizations ("ONO"), and the Commissioner of the ONO would be elected in a manner similar to judges. Ben-Ner and Van Hoomissen, 4 Nonprofit Management and Leadership at 395, 408-09 (cited in note 4).

189 Fishman, 34 Emory L J at 670-71 (cited in note 26) (arguing instead that "[e]xpanding the use of relators could complement attorney general enforcement yet avoid the dangers of broadening standing by members of the public" and defining a relator as "a party who may or may not have a direct interest in a transaction, but is permitted to institute a proceeding in the name of the people when that right to sue resides solely in the attorney general").

190 Brody, 41 Vill L Rev at 497-99 (cited in note 29).

191 Wilson, 12 Prob \& Prop at 53 (cited in note 36 ).

192 See <http://www.nonprofits.org/library/gov/urs/> (visited Mar 4, 2000). 
profits.org web site. ${ }^{193}$ Further moves toward uniformity in registration should continue in order to simplify registration for online solicitors.

In order to do so, information from the uniform registration forms should be placed in a database coordinated and controlled by state officials and available to all the states. ${ }^{1 / 4}$ States could accept participation in this database in lieu of separate filings. Charities would have to indicate in which states they intend to solicit (all states if they have a web site that they do not block or filter in any way), and each state would receive automatic notification upon their registration. While there is a cost to doing this, charging charities a higher fee for this system may be cheaper than requiring charities to register separately in all jurisdictions that require it. Current registration fees are minimal; ${ }^{195}$ even a 100 or 200 percent increase would be bearable.

State laws also often exempt very small charities from registration. ${ }^{196}$ Truly small, local charities with web sites could be exempt from a national database as well. Charities that do not wish to solicit nationally via the web can continue with the current system and avoid the imposition of higher registration fees. States already cooperate in this area. ${ }^{\mathrm{k} 7}$ For example, state charities offices in New Hampshire, New Mexico, and Oregon are collaborating with the Multi-State Filter Project to allow electronic filing of IRS Form 990, which many states require. ${ }^{1 / 8}$ States could harness the web here as well, allowing charities to register in the database via the Internet.

Charities can police themselves as well. Web sites can have disclaimers that donations will be accepted only from residents of particular jurisdictions. To enforce such a provision, charities can require the presentation of an individual's home address prior to accepting a contribution. If a charity does not accept donations online via credit card, but instead offers a phone number or mailing address for web surfers to use, the initial disclaimer could still be effective. While some states define a solicitation to occur where it is received regardless of whether a donation is actually made, changing this definition for Internet solicitations might be one of the adaptations called for by

193 See <http://www.nonprofits.org/library/gov/urs/o_appndx.htm\#alabama> (visited Apr 3, 2000 ) (providing overview of registration requirements of the thirty-eight states and the District of Columbia that require registration).

194 States that do not currently accept the uniform form might choose to participate or might choose to continue in a separate manner.

195 See, for example, Conn Gen Stat Ann § 21a-190b (requiring a twenty dollar filing fee for organizations that register to solicit).

196 See, for example, NY Executive Law $\$ 172$-a(2)(d) (exempting charities that raise less than $\$ 25,000$ per year and do not use professional fundraisers).

197 The uniform registration forms are an example of this.

198 See <http://www.bway.net/ hbograd/highlights.html> (visited Mar 18, 2000). 
web fundraising. ${ }^{199}$ States can amend their definitions of solicitation to exclude Internet solicitations, as long as there is a specific disclaimer stating in which states the charity does and does not solicit, and a means of blocking contributions from the state's residents. Additionally, future advances in technology may allow web site operators to block access to a site entirely based on the geographic location of the Internet user. ${ }^{200} \mathrm{~A}$ charity could then avoid soliciting, and its accompanying registration and reporting requirements, in designated locales.

In the context of taxes on Internet transactions, the Advisory Commission on Electronic Commerce, created by the Internet Tax Freedom Act, has recognized the need to "be respectful of sovereignty of state and local jurisdictions," as well as the need for "state and local governments [to] make every effort to simplify current sales and use tax systems. ${ }^{201}$ Similarly, with most states and some localities requiring solicitors to register, simplification in registration could ease the burden for charities while still encouraging charitable giving and protecting legitimate state interests. Further moves toward uniform requirements could do so, as could a coordinated database.

Even if states do not adopt these simplifying schemes, states still have authority to regulate online solicitors. But this does not imply that states will become onerous regulators. State charities officials do not believe that they should micromanage charities. ${ }^{2 n}$ They "do not view themselves as the 'ultimate owners' of the underlying assets of all charitable organizations, though they do represent the public, donors, and beneficiaries in certain legal proceedings."

States have already lost one means of controlling fraud with the loss of fundraising cost limits. ${ }^{24}$ While we may desire a diverse and competitive nonprofit sector, uncontrolled Internet fundraising may harm charities more than it helps. ${ }^{205}$ While charities may resist online

199 See, for example, Ark Code Ann 1198 § 1(13).

200 See Lessig, 113 Harv L Rev at 515-18 (cited in note 20) (discussing possible uses of Internet protocol addresses to identify and screen users).

201 Advisory Commission on Electronic Commerce, Issues and Policy Options Paper: Final Draft Submitted to the Commission from the Report Drafting Subcommittee, 12-3-99 at 2, available online at <http://www.ecommercecommission.org/document/issuesPO.pdf $>$ (visited Mar 6, 2000).

202 Bograd, The Role of State Attorneys General at 5-6 (cited in note 32) (expressing views of the directors of charities offices in Connecticut, Massachusetts, and New York, which are three of the larger and better-staffed offices).

203 Id at 6.

204 See Citizens for a Better Government, 444 US at 622.

205 Espinoza, 64 S Cal L Rev at 667 (cited in note 19) ("An increasingly diverse and growing nonprofit marketplace was the goal of the Court in Citizens for a Better Government. And it may be that increased competition and growth of the nonprofit sector will increase community involvement, local volunteerism, and service provided to local beneficiaries who are not currently helped by large national charities or the government. On the other hand, these benefits are likely to be offset by the loss of donor confidence and the scramble for market share con- 
regulation, state registration requirements might in fact help charities. While most legitimate charities engage in "balanced" fundraising and respect their donors, ${ }^{205}$ there have been many reports of abuses in the nonprofit sector, which may discourage prospective donors. ${ }^{207}$ State regulation may help to contain scandals and preserve public confindence in charitable organizations.

\section{CONCLUSION}

While some commentators have criticized states' attempts to regulate the Internet, this Comment demonstrates that state regulation of online solicitations is not only feasible but the best solution to the problems of charitable fraud. The advent of online fundraising has multiplied the possibilities for charitable fundraising. This is mostly a positive development-we desire a strong and vibrant nonprofit sector, and state and federal tax laws both encourage charitable donations. However, the possibilities for fraud are multiplied as well.

Traditional state police powers and interests in preventing consumer fraud remain just as valid when applied to the new medium of the Internet. States should not lose any power they have to protect their citizens simply because the method of reaching their citizens has changed.

Moreover, charities that obtain the benefits from soliciting in a jurisdiction should have to bear the corresponding burdens. While we may want to encourage the growth of the Internet and online commerce, state regulation has not been preempted in this area and should not be.

This does not imply that no changes are necessary. Further uniformity in registration requirements and cooperation among states can ease the burden on charities while still protecting legitimate state interests. The proposals in this Comment are a start in that direction.

ducted through marginal fundraising.").

206 Id at 654 ("Of course, most charities do not milk the public down to the last marginal cent. Because they understand that giving may be chilled and because of their sincere commitment to charitable causes, charities generally undertake balanced fundraising. This enables charities to efficiently maintain the interest of prior donors and, at the same time, provide for reasonable growth in their donor base.") (footnote omitted).

207 Ben-Ner and Van Hoomissen, 4 Nonprofit Management \& Leadership at 394 (cited in note 4). 


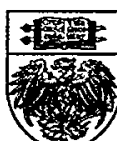

